\title{
MEĐUNARODNI ASPEKTI UPRAVLJANJA LJUDSKIM RESURSIMA U POSLOVNOM AMBIJENTU
}

\author{
INTERNATIONAL ASPECTS OF HUMAN RESOURCE \\ MANAGEMENT IN BUSINESS ENVIRONMENT
}

\author{
Marija Živanović \\ Gradska uprava Grada Kragujevca, Trg slobode 3, 34000 Kragujevac, Republika Srbija
}

\section{(C) MESTE NGO}

\section{Sažetak:}

Bilo koja kompanija koja danas posluje na tržištu suočava se sa problemom globalizacije. Profitabilan nastup kompanije uslovljen je postojanjem dobrog marketing koncepta tj. optimalnim kombinacijama instrumenata marketinga. Budućnost profitabilnog poslovanja opredeljuje efikasnost uključivanja ljudskih resursa. Oni su osnovna premisa za uspešno sprovođenje marketinških aktivnosti u preduzeću. Svi elementi marketing miksa su podjednako značajni, svaki od njih ima svoju ulogu i područje uticaja na ciljni tržišni segment, međutim bez dobro organizovanog i efikasnog sistema komuniciranja kompanije sa tržištem, odnosno šire posmatrano - sa okruženjem, ona neće moći uspešno da ostvari svoj komunikacioni ili ekonomski cilj. Marketinška strategija kompanije će se bazirati na tome koju poziciju u odnosu na direktnu konkurenciju na tržištu ima odabrani proizvod u očima potrošačke ciljne grupe (idealnih mušterija). Upravljanje ljudskim resursima kao proces vođenja kadrovske politike treba da osigura što veću produktivnost zaposlenih. Za prognozu uslova u kojima će kompanije poslovati u budućnosti neophodna je adekvatna uloga ljudskih resursa. U radu se prikazuju aktuelni pristupi međunarodnog upravljanja ljudskim resursima.

\section{Ključne reči:}

ljudski resursi, međunarodni marketing, menadžment

\begin{abstract}
:
Any company that operates in the market today is faced with the problem of globalization. Profitable company performance is conditioned by the existence of a good marketing concept, i.e. optimal combination of instrument marketing. The future profitable operations determine the efficiency of the inclusion of human resources. They are the basic premise for the successful implementation of marketing activities in the company. All elements of the marketing mix are equally important, each of them has its own role and

Adresa autora:

Marija Živanović

莑" marija milicevic kg@yahoo.com area of impact on the target market segment, but without a well-organized and efficient system of communication with the company's market and more broadly - with the environment, it will not be able to successfully achieve their communication or economic objective. The marketing strategy of the company will
\end{abstract}




\section{Živanović M. Međunarodni aspekti upravljanja ljudskim resursima}

FBIM Transactions Vol.1 No.1 pp. 111-118

be based on the fact that the position in relation to the direct competition in the market has chosen product in the eyes of the consumer target groups (ideal client). Human resource management as a process of keeping the personnel policy should ensure greater employee productivity. For the prediction of conditions in which the company will operate in the future, it is necessary to appropriate the adequate role of human resources. The paper presents current approaches to the international human resource management.

Keywwords: human resources, international marketing, management

\section{Uvod}

Rad je posvećen analizi uloge ljudskih resursa $u$ poslovnom sistemu. Cilj je, da se ukaže na značaj zaposlenih i objasni uloga ljudskih resursa u pružanju podrške efikasnom poslovanju.

Neophodno je predstaviti suštinu i značaj razvoja kadrova, njihovog upravljanja kao procesa vođenja kadrovske politike u domenu poslovanja više povezanih preduzeća, kao i način na koji oni funkcionišu u kompanijama koje posluju na globalnom nivou.

Implementacija i uspostavljanje procesa permanentnog zapošljavanja kadrova osnov je za unapređenje produktivnosti poslovanja preduzeća kao i kreiranja konkurentne prednosti na međunarodnom tržištu.

\section{Analiza ljudskog faktora u međunarodnom marketingu i menadžmentu}

Sa procesom globalizacije i ekspanzijom kvaliteta, kao i težnjom da se ostvari maksimalna produktivnost uz minimalne troškove, ljudski resursi su zauzeli centralno mesto u strateškom poslovanju. Preduzeća pored finansija i tehnologije moraju imati lojalne zaposlene kako bi mogla da opstanu u konkurentnom okruženju koje se sve brže menja.

Međunarodni marketing potencira uspostavljanje i održavanje tesnih i dugoročnih relacija kupaca i zaposlenih, stavljajući ih u središte svojih poslovnih odluka, prilagođavajući im se i nastojeći da zadovolji sve njihove potrebe. Od suštinskog značaja za uspeh u preduzeću je zapošljavanje pravih ljudi u pozitivnom poslovnom ambijentu, $s$ ciljem ostvarivanja konkurentske prednosti.

Međunarodni menadžment podrazumeva efikasno korišćenje ljudskih resursa kao i njihovo usmeravanje prema datim ciljevima u preduzeću. Uspeh u usmeravanju ljudi prema postavljenim ciljevima zavisi od aktivnosti međunarodnih menadžera kao i njihove sposobnosti da na pravi način iskoriste raspoložive resurse.

Kadrovi predstavljaju bazu poslovanja preduzeća. Sama kadrovska struktura inicira podizanje stručnog nivoa i osposobljavanje pojedinaca da izvršavaju složenije zadatke u preduzeću.

\subsection{Unapređenje marketinga u uslovima poslovanja kriznog menadžmenta}

Za uspeh preduzeća na globalnom nivou, neophodni su ne samo tehničko-tehnološko znanje, već i sposobnost da se to znanje upotrebi u zadovoljenje potreba kupaca. U cilju postizanja prosperiteta preduzeća važno je da menadžeri budu istovremeno i lideri efikasnog ekonomskog poslovanja (Đuričin, Janošević, \& Kaličanin, 2009).

Suština marketing filozofije je da preduzeće ne bude orijentisano na proizvodnju samo proizvoda/usluga, već i na kupovinu kupaca.

Lojalnost kupaca na tržištu je posebno važna u kontekstu eksponencijalnog rasta preduzeća.

Globalizacija, tehnološki razvoj, deregulacija otvaraju nove šanse preduzećima i njihovim konkurentima.

Prema istraživanjima svetske i naše nauke i prakse veliki broj preduzeća ima poteškoća kod proširenja na globalno tržište (Senić \& Lukić, 2009).

\subsection{Međunarodni marketing i upravljanje ljudskim resursima}

Sam koncept međunarodnog marketinga definiše se kao inicijator kreativne funkcije biznisa. Uz porast globalizacije, kao značajnog fenomena poslovanja, menadžeri naših kompanija bivaju sve više okupirani razvojem kako domaćeg, tako i međunarodnog tržišta (Đorđević, 2005).

Za prognozu uslova u kojima će kompanije poslovati u budućnosti neophodna je adekvatna uloga ljudskih resursa. Poslovna vizija preduzeća, obim događaja, kratko vreme za donošenje odluka 
kao i potreba da se u svakoj situaciji donese najbolje moguće rešenje, povećavaju uloge menadžera i podstiču njihovu kreativnost u preduzećima.

\subsection{Analiza okruženja u međunarodnom poslovanju}

Okruženje predstavlja šansu za svako preduzeće, ali $\mathrm{u}$ konvencionalnom marketingu i pretnju, ukoliko menadžeri ne shvataju da je uloga preduzeća nekada i iniciranje promena.

S obzirom da su važna tri tipa okruženja, i to: opšte, konkurentsko i interno, mora se imati u vidu da je neophodno stalno unapređenje marketinga kao imperativa za razvijanje ekonomskih i marketinških faktora okruženja. Povećanje dinamičnosti, kompleksnosti, kao i sve veće zavisnosti preduzeća od okruženja dovodi do zaokreta u stvaranju jednog strategijski orijentisanog sistema upravljanja preduzećem. Ubrzan privredni razvoj sugeriše nova znanja koja moraju biti u skladu sa istim iz okruženja, jer je to uslov opstanka na današnjem globalnom tržištu. Promene koje se dešavaju u spoljnjem okruženju, posebno u novim tehnologijama, utiču na strategiju i planiranje $u$ organizacijama.

\section{Međunarodni aspekt upravljanja ljudskim resursima}

Danas sve veći broj kompanija izložen takmičarskim pritiscima, deluje preko međunarodnih granica u potrazi za resursima. Međunarodna aktivnost jedne kompanije ima ključnu ulogu u determinisanju prava zaposlenih kao i strukture odeljenja za ljudske resurse.

Strateško upravljanje ljudskim resursima treba sa jedne strane da uskladi strategijske potrebe organizacije, a sa druge efikasnije uposli ljudske resurse.

Strateški pristup ljudskim resursima podrazumeva i investiranje u ljudske resurse, jer udeo ljudskog kapitala određuju znanja i veštine koje pojedinci stiču. Znanja i veštine u velikoj meri utiču na performanse zaposlenih, tako da je obrazovanje vrlo značajan faktor ekonomskog razvoja jedne zemlje i pojedinačnih kompanija. To stremi ka ostvarenju ekonomskih i socijalnih ciljeva.

\subsection{Nacionalno poreklo ljudskih resursa}

Savremena globalna tržišta potenciraju da je najvažnije razmišljati drugačije od ostalih, do realizacije samih ideja.

Profitabilan nastup kompanije na tržištu je uslovljen postojanjem dobrog marketing koncepta, tj. optimalne kombinacije instrumenata marketinga.

Brojne kompanije u svetu u poslovanju sa nerazvijenim zemljama angažuju svoje stručne kadrove. Nasuprot tome, kada je reč o uspostavljanju poslovnih odnosa sa razvijenim zemljama angažuju kadrove iz tih zemalja.

Danas, brojni gradjani jedne zemlje žive i rade u drugoj zemlji, te je proces angažovanja ekspatriata u uskoj korelaciji sa specifičnim tehničkim veštinama.

$\mathrm{Na}$ taj način kompanije primenjuju strategiju standardizacije u nastupima na medjunarodnom tržištu.

Kao dokaz globalne orijentacije poslovanja navodi se angažovanje eksperata iz inostranstva koji poseduju specijalizovana znanja i veštine od strane domaćih kompanija. Ova značajna strategija korišćenja ljudskih resursa ima sve širu primenu u globalnim uslovima poslovanja.

\subsection{Međunarodna politika ljudskih resursa}

Međunarodna politika igra značajnu ulogu u određivanju položaja zaposlenih u poslovnom svetu. Ključni pristupi u sagledavanju međunarodne politike ljudskih resursa jesu:

\section{- Etnocentrična}

- Policentrična

- Geocentrična orijentacija

Etnocentrična podrazumeva angažovanje menadžera iz našeg okruženja, što može usloviti brojne barijere u lokalnoj sredini, jer zaposleni u jednoj firmi mogu pomisliti da strani menadžeri nemaju razumevanja za njihove potrebe (Đorđević, 2005). Primera radi, mogu se uočiti dve osnovne razlike između japanskih i američkih kompanija. Japanski direktori zastupaju stav da kompanija postoji zbog zaposlenih i akcionara, dok američki nastoje da maksimiziraju interese akcionara. Ova orijentacija se primenjuje najčešće kada preduzeće otpočinje proces internacionalizacije poslovanja. 
Policentrična uključuje lokalne menadžere, koji pripadaju lokalnoj kulturi i podrazumeva izvestan stepen autonomije u donošenju njihovih odluka. Obuku ovih menadžera organizuju velike međunarodne kompanije. $U$ policentričnim orijentacijama poslovanja stvarni vlasnik kompanije se samo u retkim prilikama identifikuje.

U Geocentričnoj orijentaciji menadžment multinacionalnog preduzeća zastupa tezu da je neophodno globalno razmišljanje kako bi se preduzeće uspešno prilagodilo uslovima u okruženju. Geocentrična orijentacija pruža pomoć kompanijama u pronalaženju globalnih menadžera. $\mathrm{Na}$ taj način se može ojačati mreža upravljanja, idealna za sprovođenje međunarodnog poslovanja.

\subsection{Značaj upravljanja ljudskim resursima}

Insistiranjem na predstavljanju jednog proizvoda kompanije, na drugačiji način, u prvi plan izlazi ljudski potencijal, kao i splet originalnih, kreativnih i inovativnih ideja. Od zaposlenih u prvoj liniji poslovanja zahteva se izvanredno zalaganje kao $\mathrm{i}$ besprekorna usluga, koja nadmašuje konkurentsku prirodu.

Specifičnosti i značaj ljudskih resursa (Jovanović-Božinov \& Cvetkovski, 2004) jesu:

- „judski resursi, za razliku od ostalih resursa, mogu da stave u funkciju sve umne, fizičke i druge potencijale kojima raspolažu;

- ljudski potencijali, dobro ukomponovani i usmereni u pravcu timskog koncepta rada, obezbeđuju sinergijski efekat, koji ukupne rezultate rada čini većim od pojedinačno ostvarenih rezultata;

- rezultati rada pojedinaca, grupa, timova i organizacije u celini, između ostalog, zavise i od ponašanja i motivisanosti zaposlenih i menadžera u kompanijama;

- jedino čovek može oblikovati viziju, projektovati strategiju, imati ideje, stvarati kreacije, osmišljavati nove proizvode i slično;

- pojedinačna znanja, sposobnosti i kvalitet predstavljaju osoben i po mnogo čemu jedinstven potencijal organizacije, naročito ako se dobro ukomponuju i na pravi način usmere ka ostvarivanju organizacionih ciljeva;

- ljudski resursi imaju dugoročan uticaj na poslovanje organizacije, između ostalog i zbog toga što se dejstvo određenih odluka i promena može godinama odražavati na ukupne efekte poslovanja;

- odnos organizacije prema ljudskim resursima ima višestruko dejstvo - ekonomske, socijalne i zdravstvene prirode;

- ljudski resursi imaju sposobnost samoobnavljanja i razvoja, tim pre što se upotrebom ne obezvređuju i ne smanjuju, već potvrđuju i povećavaju;

- ljudski resursi su povezani sa svim poslovnim funkcijama;

- investiranje u ljudske resurse je isplativije od investiranja u bilo koje druge resurse."

\subsection{Ciljevi upravljanja ljudskim resursima}

$\mathrm{U}$ svrhu postizanja određenih ciljeva u organizaciji, menadžment ljudskih resursa mora da ispuni određene zahteve, koji će uticati na poboljšanje rada zaposlenih, a samim tim i njihovu veću produktivnost u organizaciji. Kroz zadovoljenje $\mathrm{i}$ ispunjenje zahteva osnovnog i najvrednijeg resursa u preduzeću, dolazi se do ispunjenja ciljeva, kojima se teži. Ukoliko menadžment ljudskih resursa nije u stanju da upravlja ljudskim resursima, to može da utiče na poslovanje, a u najgorem slučaju i opstanak te organizacije.

Međunarodni aspekt upravljanja ljudskim resursima obuhvata ostvarivanje sledećih ciljeva:

Funkcionalni cilj - funkcija upravljanja ljudskim resursima jeste da pruža doprinos organizaciji, kako bi ona ostvarila svoje ciljeve i realizovala organizacionu strategiju. Resursi treba što racionalnije i efikasnije da se koriste, u ostvarenju organizacionih ciljeva.

Organizacioni cilj - kao što smo već istakli, za organizaciju je ključni faktor ljudski resurs. Menadžment ljudskih resursa utiče na efikasnost kao i motivaciju zaposlenih u preduzeću.

Društveni cilj - u svakodnevnim ljudskim odnosima društvene norme kao i sistemi vrednosti su veoma važni u ostvarivanju dobre komunikacije. Biti etički i društveno odgovoran prema potrebama i izazovima društva i minimizirati negativne uticaje tih zahteva na poslovne organizacije je takođe jedan od značajnih ciljeva, ne samo za upravljanje ljudskim resursima, već i menadžmenta u celini.

Lični cilj - lična satisfakcija zaposlenih je najvažnija za svaku organizaciju, ali nije dovoljno zadovoljiti zaposlene samo u poslovnom smislu, već je 
neophodno pomagati im i u ostvarenju njihovih ličnih ciljeva. Samo na taj način može se zadobiti njihovo poverenje, a zaposleni će biti zadovoljni i motivisani za napredak kao i lični doprinos organizaciji.

Svaki od navedenih ciljeva bitno utiče na upravljanje ljudskim resursima, čime se značajno unapređuje poslovanje u organizaciji. Preduslov za uspeh je svakako konstruktivna saradnja svih nivoa menadžmenta kao i zaposlenih.

\section{Organizacione karakteristike i primena ljudskih resursa u međunarodnom poslovanju}

\subsection{Faze procesa upravljanja ljudskim resursima}

Proces upravljanja ljudskim resursima obuhvata sedam osnovnih aktivnosti, i to (Čerović, 2009):

1) Planiranje ljudskih resursa, predviđa da se potrebe za osobljem zadovoljavaju kontinuirano $i$ na adekvatan način,
a) analizom unutrašnjih faktora;
b) analizom okruženja .

2) Regrutovanje, čiji je cilj adekvatan izbor kandidata za određeni posao, a prema planu ljudskih resursa,

3) Selekcija, koja uključuje podnošenje referentne liste, proveru znanja, intervjue i sl.;

4) Uvođenje u radnu sredinu (socijalizacija), upoznavanje sa organizacijom, korporativnom kulturom, poslovima;

5) Procena učinka, pri čemu mali učinak zahteva korektivne mere, a visok učinak - nagrade;

6) Obuka i usavršavanje koji su fokusirani na povećanje sposobnosti radnika i pripremu za novo radno mesto. Firme koje se takmiče na globalnom tržištu često ugrađuju programe za globalnu obuku. Programi obuke u okviru naših preduzeća se sastoje od grupnih sastanaka, seminara, kurseva stranih jezika i $d r$.

7) Unapređenje, premeštaji, degradiranja i razrešenja kao odraz vrednosti nekog radnika za organizaciju.

Koraci koji nam pomažu da shvatimo kako teče sam proces upravljanja ljudskim resursima jesu (Dessler, 2007):
- Analiza poslovanja (utvrđivanje prirode posla svakog zaposlenog);

- Planiranje radnih mesta i regrutovanje kandidata za posao;

- Odabir kandidata za posao;

- Usmeravanje i obuka novih radnika;

- Procena učinka;

- Upravljanje nadnicama i platama (kako se odužiti zaposlenima za radni učinak);

- Pružanje podsticaja i beneficija zaposlenima;

- Komunikacija (intervjui, savetovanja, sankcije);

- Obuka i usavršavanje zaposlenih.

Politika upravljanja kadrovima obuhvata sledeće konstitutivne elemente (Torrington, Hall, \& Taylor, 2004):

- Prisustvo na sigurnom radnom mestu;

- Regrutovanje pravih ljudi;

- Širok spektar samostalnih timova kao i decentralizaciju;

- Visoke nadoknade koje su u tesnoj vezi sa organizacionim rezultatima rada;

- Velika izdvajanja za obučavanje kadrova;

- Smanjivanje razlika u statusu kao i razmenu informacija.

\subsection{Faktori koji utiču na efikasnost zaposlenih}

Izvlačenje najboljeg iz radne snage oduvek je bio najvažniji zadatak menadžmenta, uključujući i razdoblje koje je prethodilo razvoju naučnih metoda menadžmenta.

Ciklus radne efektivnosti podrazumeva tri ključna aspekta efektivnog rada koji se kao takvi mogu koristiti kao koraci ka postizanju rezultata rada zaposlenih (Torrington, Hall, \& Taylor, 2004)

1) Planiranje rada - planiranje radne efektivnosti uključuje jedinstven stav o očekivanim rezultatima rada menadžera i zaposlenih koji se iskazuje tradicionalnim opisom posla, ključnim odgovornostima, standardima rada, određenim ciljevima i osnovnim kompetencijama. 
2) Podrška u ostvarivanju rezultata - uloga menadžera jeste, da omogući ostvarivanje zadatih ciljeva svojim saradnicima. Postoje nepredviđene prepreke u vezi s njima, situacije koje će zahtevati ponovno preispitivanje rezultata kao i razmenu unutrašnjih, ma kako osetljivih, informacija.

Stalni pregled postignutih rezultata podrazumeva i zajednički uvid $u$ to kako druga strana napreduje i šta je moguće uraditi da bi jedni drugima bili od pomoći.

Faktori koji utiču na efikasnost zaposlenih jesu:

- motivacija zaposlenih;

- organizaciona kultura;

- usmerenost menadžmenta ka zaposlenima;

- kvalitetna komunikacija na svim nivoima i

- kreativna radna sredina.

\subsection{Motivacija zaposlenih}

Menadžeri se često fokusiraju na pitanja u vezi sa različitim pristupom poslu od strane svojih saradnika. Unutar samo jedne organizacije, odeljenja ili tima jedni se trude raditi više i bolje, dok drugi rade što je moguće manje. Na pitanja šta kao menadžeri mogu učiniti povodom zalaganja na radnom mestu i rezultata koji proizlaze iz istoga ali i o razlozima zbog kojih se zaposleni promijene, počnu kasniti na posao, izostajati, manje raditi $\mathrm{i}$ slično, odgovori se nalaze u sferi motivacije i razumevanja nje same.

Ovo postaje još važnije usred trenutnog ekonomskog pada i povećanih izazova na koja preduzeća moraju adekvatno i brzo da odgovore.

Kako mogu da motivišem članove svog tima? pitanje je koje izostavlja esencijalne motivacione razloge, motive onoga ko radi, a ne njegovog menadžera.

Motivacija je psihološka karakteristika ljudi koja je u direktnoj, uzročno - posledičnoj vezi sa stepenom individualne predanosti. Čine je faktori koji izazivaju, kanališu i podržavaju ljudsko ponašanje $u$ određenom pravcu.

Motivacija se može posmatrati unutar okvira različitih ponašanja ljudi između dve krajnosti: refleksne radnje i stečenih navika.

Kako se u menadžmentu značaj motivacije izjednačava sa značajem strategijskih planova, jer predstavljaju input $u$ procesu dizajniranja organizacionih odnosa i raspodele moći unutar njih, tako se motivacija zaposlenih dovodi u najužu vezu sa posvećenošću ciljevima organizacije, lojalnošću poslodavcu i efektivnom i efikasnom radu (Čerović,2009).

Organizaciona kultura može biti snažan motivacioni faktor ukoliko se (Jovanović-Božinov \& Cvetkovski, 2004):

- "njene osnovne vrednosti vezuju za ljude, kvalitetan rad i kvalitetne usluge;

- stalno prilagođava potrebama i zahtevima sposobnih i kreativnih ljudi;

- njome razvija povoljna klima za rad, inovacije, preuzimanje odgovornosti, osposobljavanje i razvoj;

- njome favorizuje i na adekvatan način vrednuje i nagrađuje dobar i uspešan rad;

- njome otvara prostor za uspostavljanje i negovanje intenzivnih i neposrednih komunikacija o svim značajnijim pitanjima vezanim za rad i njihovo rešavanje;

- u organizaciji stvara i širi osećaj uspeha, zadovoljstva i ponosa zbog dobrog rada i visoke individualne i organizacione uspešnosti;

- u organizaciji, odnosno među zaposlenima, širi duh zajedništva i brige o ljudima itd."

\subsection{Primena softvera (SAP) u službi ljudskih resursa}

Svako preduzeće, bez obzira na veličinu, zapošljava određeni broj ljudi. Ljudski resursi često predstavljaju i najveći kapital jedne organizacije. Zaposleni poseduju lične osobine, znanja, veštine, iskustva i kvalifikacije koja zajedno omogućavaju funkcionisanje organizacionog sistema. Uspešna komunikacija sa kupcima kao i dobavljačima, ideje za nove proizvode, uslov su za unapredjenje poslovanja na osnovu kojih organizacija ostaje funkcionalna i konkurentna. Poslednjih godina su učinjeni veliki napori u razvoju procesa koji pružaju pomoć preduzećima pri zapošljavanju, zadržavanju u svojoj firmi i podržavanju talentovanih ljudi, kao i u merenju produktivnosti radne snage.

Pojedini softveri takodje pružaju podršku primanju novih kadrova. SAP ERP Human Capital Management je softverski paket koji zaposlenima $u$ kadrovskoj službi pomaže pri zapošljavanju novih ljudi, sprovođenju programa obuke, beleženju i 
merenju performansi zaposlenih, vođenju evidencije prisustva na poslu itd. Pri tome, zaposleni mogu sami da obavljaju određene zadatke, koristeći selfservice mogućnosti kao što su prijavljivanje za korišćenje slobodnih dana i godišnjih odmora, upoznavanje sa beneficijama, kreiranje izveštaja o vremenu provedenom na novim projektima i sl. Time se oslobađa deo vremena koje zaposleni u HR službi moraju da provedu na takvim zadacima i omogućava im se da se duže i bolje koncentrišu na zahtevnije poslove.

Ranije su se procesi kao što su zapošljavanje $i$ obuka zaposlenih uglavnom odvijali nezavisno, sa podacima koji su se prikupljali i čuvali u odvojenim sistemima. SAP ERP Human Capital Management je omogućio integraciju svih takvih podataka kroz centralizovano skladište podataka za svakog zaposlenog.

Ovom integracijom, svi potrebni podaci o svakom pojedinačnom zaposlenom su dostupni menadžerima i HR službi i na taj način omogućavaju jedinstven sistem za zapošljavanje, obuku i unapređivanje zaposlenih.

\subsection{Strateški pristup upravljanju ljudskim resursima u međunarodnom poslovanju}

Strategija je po definiciji veština korišćenja načina da se ostvare ciljevi. Naime, reč je o planskoj odluci kojom se polazeći od ciljeva i politike preciziraju načini njihovog realizovanja u poslovanju preduzeća.

Smatraju se uspešnim one strategije koje se zasnivaju na ljudskim resursima, kapitalnim dobrima, tržišnim ciljevima i ujedno streme ka postizanju sinergije i kompetentnosti. To se smatra glavnim motivom u sagledavanju konkurencije. Kontinualno prilagođavanje i napredovanje $u$ savremenoj ekonomiji znači stvaranje novih vrednosti za kadrove, jer u protivnom oni ne mogu da podstiču kupovinu proizvoda i usluga.

Strateški pristup upravljanju ljudskim resursima u međunarodnom poslovanju može biti shvaćen kao „šema plana zapošljavanja i aktiviteta ljudskih resursa kako bi se ciljevi organizacije efikasno ostvarili” (Šušnjar, 2003). Uspeh procesa strategijskog upravljanja zavisi od opsega funkcije ljudskih resursa.

\section{ZAKLJUČAK}

Turbulentnost ekonomskih tokova na globalnom planu ozbiljan je izazov međunarodnom marketingu kompanija. Menadžeri globalno orijentisanih preduzeća pri razvoju marketing strategija moraju respektovati razlike između nacionalnog i međunarodnog marketinga i tržišta.

Jedan od ključnih strategijskih zadataka međunarodnog menadžmenta danas postaje uspešno upravljanje ljudskim resursima i u kontekstu toga izgradnja adekvatnog sistema motivacije.

Podsticanje uspešnosti na radu uključuje aktivnosti motivacije, kreativnosti kao i ocenjivanja uspešnosti.

Poslovna organizacija, tj. menadžment dizajnira radne zadatke u skladu s organizacionim ciljevima, zapošljava ljude s potrebnim znanjima i umećima te in trenira, motiviše i nagrađuje. To su neki od temeljnih aspekata angažmana ljudskih resursa koji omogućavaju uspešno delovanje, a vrednovanje rada služi prvenstveno praćenju realizacije organizacionih ciljeva kako bi se na pravi način razvijala korporativna strategija i adaptirala na okruženje.

Uspešni poslovni sistemi danas imaju u fokusu uključivanje ljudskih resursa kao i njihov uticaj na primenu novih tehnologija, proizvode, procese i usluge.

Da bi se efikasno upravljalo aktivnostima, nužno je precizirati autoritete i odgovornosti, odrediti zadatke i rasporediti na nosioce kao i obezbediti adekvatan sistem koordinacije i vođenje ukupnog procesa implementacije.

Sam proces globalizacije tržišta $u$ velikoj meri afirmiše kvalitet ljudskih resursa kao fundamentalni izvor konkurentske prednosti.

\section{Citirani radovi}

Čerović, S. (2009). Strategijski menadžment u turizmu. Beograd: Univerzitet Singidunum.

Dessler, G. (2007). Osnovi menadžmenta ljudskih resursa. Beograd: Data Status.

Đorđević, M. (2005). Međunarodni marketing. Kragujevac: Ekonomski fakultet. 


\section{Živanović M. Međunarodni aspekti upravljanja ljudskim resursima}

\section{FBIM Transactions Vol.1 No.1 pp. 111-118}

Đuričin, N., Janošević, S., \& Kaličanin, M. (2009). Menadžment i strategija. Beograd: Centar za izdavačku delatnost Ekonomskog fakulteta Univerziteta u Beogradu.

Jovanović-Božinov, M., \& Cvetkovski, T. (2004). Menadžment ljudskih resursa. Beograd: Begatrend univerzitet primenjenih nauka.

Senić, R. (1999). Marketing menadžment. Kragujevac: Ekonomski fakultet Univerziteta u Kragujevcu.

Senić, R., \& Lukić, S. (2009). Krizni menadžment. Banja Luka: Panevropski univerzitet "Aperion".

Šušnjar, G. (2003). Upravljanje Ijudskim resursima. Kragujevac: Ekonomski fakultet.

Torrington, D., Hall, L., \& Taylor, S. (2004). Human Resource Management. London: Prentice Hall.

Datum prve prijave:

Datum prihvatanja članka:
10.09.2012.

16.11.2012.

\section{Kako citirati ovaj rad?}

Style - APA Sixth Edition:

Živanović, M. (2013, 01 15). Međunarodni aspekti upravljanja ljudskim resursima u poslovnom ambijentu. (Z. Čekerevac, Ed.) FBIM Transactions, 1(1), 111-118. Retrieved from

www.meste.org/fbim/FBIM 1 2013/ 12.pdf. doi: 10.12709/fbim.01.01.01.12

\section{Style - Chicago Fifteenth Edition:}

Živanović, Marija. "Međunarodni aspekti upravljanja ljudskim resursima u poslovnom ambijentu." Edited by Zoran Čekerevac. FBIM Transactions (MESTE NVO) 1, no. 1 (01 2013): 111-118.

Style - GOST Name Sort:

Živanović Marija Međunarodni aspekti upravljanja ljudskim resursima u poslovnom ambijentu [Journal] = Međunarodni aspekti upravljanja ljudskim resursima // FBIM Transactions / ed. Čekerevac Zoran. - Beograd : MESTE NVO, 01 15, 2013. - 1 : Vol. 1. - pp. 111-118.

Style - Harvard Anglia:

Živanović, M., 2013. Međunarodni aspekti upravljanja ljudskim resursima u poslovnom ambijentu. FBIM Transactions, 15 01, 1(1), pp. 111-118.

Style - ISO 690 Numerical Reference:

Međunarodni aspekti upravljanja ljudskim resursima u poslovnom ambijentu. Živanović, Marija. [ed.] Zoran Čekerevac. 1, Beograd : MESTE NVO, 01 15, 2013, FBIM Transactions, Vol. 1, pp. 111-118. 